\title{
Local Wisdom in Supporting Food Security of Coastal Agroecosystem
}

\author{
Ida Rosada ${ }^{1 *}$, Nurliani², Farizah Dhaifina Amran ${ }^{3}$ \\ 1,2,3 Department of Agribusiness, Universitas Muslim Indonesia, Indonesia \\ *Corresponding author. E-mail: ida.rosada@umi.ac.id
}

\begin{abstract}
Food consumption is an important term in food security, because it affects the nutritional status of family members which is influenced by many factors. One of the rural community groups classified as food insecure is fishermen who lives in coastal agroecosystem. This research aims to: 1) Identify local wisdoms of coastal communities that have the potential to support household food security, 2) Analyze the impact of social and economic factors on the level of household food security. The research was conducted in March - June 2020 in Panyula Village, Bone Regency, South Sulawesi. The sample is 50 fisherman households. The resereach method is descriptive analysis and multiple linear regression analysis. The results found that: 1) The fishermen households still applying local wisdom in preparing, processing and consuming food; 2) The number of family members, household expenditure, and the value of local wisdom had a "significant effect" on the level of fishermen households' food security.
\end{abstract}

Keywords: Coastal Agroecosystems, Food Security, Local Wisdom

\section{INTRODUCTION}

The characteristics of coastal communities are different from agrarian societies. In terms of income, farmers have controllable income because of controlled harvest patterns, unlike the case with coastal communities whose livelihoods are dominated by fishermen. Fishermen struggle with the uncertain condition of the sea to get income, the income they want cannot be controlled, and the resources are open access and are at high risk, so that coastal communities, especially small fishermen, are still entangled with poverty and underdevelopment problems. There are certain issues related to ecological aspects, social, economic, and food so that coastal communities are still lagging behind [1].

According to [2], in Indonesia there are still various forms of local wisdom from indigenous groups who practice traditional ways of managing coastal resources. However, in line with the dynamic process of community life, local wisdom is degraded with fading customary values and norms due to developments and the increasingly complex challenges of life. A number of local wisdoms that have been adopted in the community are no longer behavior guidelines. For instance, local wisdom in the preservation of coastal areas to maintain and regulate environmentally friendly fishing systems has now disappeared and been replaced by a system of overexploitation.

One area that has a rich potential of coastal resources is Panyula Village, which is located in Tanete Riattang Timur District, Bone Regency. The people in this area are very dependent on the coastal environment to meet their household needs. Looking for shells and catching fish are the main activities that cannot be separated from their daily lives.

The coastal community in Panyula Village with the majority of fishermen are Moeslem, makes it very possible for local wisdom to be based on the Islamic religion which can be used as a profile of indigenous local wisdom in the area and as a reference in proenvironmental community management. Thus, the economic, religion, and the environmental sustainability can go hand in hand in the life of the people in Panyula Village.

Current researches on food security has been done a lot from the aspects of calory consumption and consumption patterns, but not many of them have linked it to local wisdom, especially in coastal agroecosystem communities from the aspects of food preparation, processing and serving of food in the family. 
The objectives of the research are to identify indigenous coastal communities that have the potential to support household food security, and to analyse social and economic factors that influence the level of household food security.

\section{METHOD}

The research was located in Panyula Village, Tanete Riattang Timur District, Bone Regency. The determination of the research location was carried out purposively with the consideration that it is located in coastal area and generally the livelihood of the community is fishermen. The population in this study were fisherman households in Panyula Village, Tanete Riattang Timur District, Bone Regency. If the population is $>100$, then we can take a sample of 10 $15 \%$ of the population [3]. There are 502 fishermen households in Panyula Village, so that by taking $10 \%$ of the amount of sample is 50 fishermen households. The sampling method used was simple random sampling. The research was held from March to June 2020.

The method of analysis used in tapping the potential of the values of local wisdom in supporting food security is qualitative descriptive method and Focus Group Discussion (FGD). To analyse the social and economic factors that influence the fishermen household's food security level is using multiple linear regression analysis. This analysis is used to find a statistical model of fishermen household food security in coastal agroecosystems which the formulation is as follows:

$\mathrm{Y} 1=\beta 0+\beta 1 . \mathrm{X} 1+\beta 2 . \mathrm{X} 2+\beta 3 . \mathrm{X} 3+\ldots \ldots . .+\beta 8 . \mathrm{X} 8+\mathrm{e}$

Where:

$\mathrm{Y}=$ score of food security level;

$\mathrm{X} 1$ = education;

$\mathrm{X} 2$ = knowledge (scoring);

$\mathrm{X} 3$ = number of family members (people);

X4 = pattern of food consumption (scoring);

$\mathrm{X} 5$ = household income (IDR/month);

$\mathrm{X} 6$ = household expenses (IDR/month);

$\mathrm{X} 7$ = whether there is side job or not (scoring);

$\mathrm{X} 8=$ value of local wisdom (scoring).

\section{RESULTS AND DISCUSSION}

\subsection{Local Wisdom on Consumption Activities}

Food security needs to pay attention to gender dynamics in the household as a unit of interaction in daily activities for basic needs. Household food security status and nutritional status of household members are the output of household production, where resources are needed as input. Resource use depends on intrahousehold variables, such as division of labor and dependency relationships. In this regard and within the household, women are the key actors in achieving household food security. One of the reasons is that food security is part of their reproductive role [4].

The production of household food security and nutrition consists of several interrelated activities, starting from the cultivation of food plants, food procurement, collection and exchange, food preparation and processing, and finally food distribution. Almost all of these activities are women's duties. However, environmental and social constraints that prevent women from accessing sufficient resources to carry out these activities in the food system create serious problems for women to carry out their reproductive responsibilities and often result in poor nutritional conditions for children [5].

Based on the results on the implementation of Focus Group Discussion (FGD), which aims to determine the different types of local knowledge on the aspects of household consumption society in coastal agroecosystem, the FGD is attended by housewives (wife of respondents fishermen) in Panyula Village, and summarized in Table 1 .

Table 1. Forms of Activities and Aspects of Local Wisdom in Coastal Community Consumption in Panyula Village, Tanete Riattang Timur District, Bone Regency, 2020

\begin{tabular}{|c|c|c|c|}
\hline \multirow[b]{2}{*}{ No. } & \multirow{2}{*}{$\begin{array}{l}\text { Forms of } \\
\text { Activities }\end{array}$} & \multicolumn{2}{|c|}{ Aspects of Local Wisdom } \\
\hline & & Material Aspects & $\begin{array}{c}\text { Non Material } \\
\text { Aspects }\end{array}$ \\
\hline 1 & $\begin{array}{l}\text { The } \\
\text { process of } \\
\text { preparing } \\
\text { food } \\
\text { ingredients }\end{array}$ & $\begin{array}{l}\text { - Preparing local } \\
\text { food raw } \\
\text { materials, such as } \\
\text { fish, shrimp, etc. } \\
\text { - Preparing } \\
\text { reserves food } \\
\text { (letting the rice } \\
\text { container empty } \\
\text { is forbidden). }\end{array}$ & $\begin{array}{l}\text { - Calculation of } \\
\text { good time/ } \\
\text { good day to go } \\
\text { to fishing. } \\
\text { - Traditions / } \\
\text { rituals } \\
\text { "Mabbaca } \\
\text { Doang" }\end{array}$ \\
\hline 2. & $\begin{array}{l}\text { The } \\
\text { process of } \\
\text { cooking } \\
\text { food } \\
\text { ingredients }\end{array}$ & $\begin{array}{l}\text { - Preparing local } \\
\text { food such as } \\
\text { lawa' bale, pule } \\
\text { utti, pule lame } \\
\text { - Using local } \\
\text { equipment } \\
\text { (furnace, pot) }\end{array}$ & 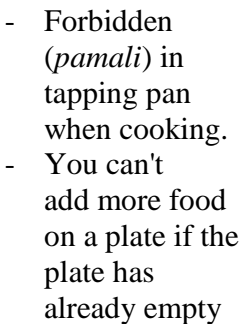 \\
\hline 3. & $\begin{array}{l}\text { The } \\
\text { process of } \\
\text { consuming } \\
\text { food }\end{array}$ & $\begin{array}{l}\text { The tradition of } \\
\text { "mappatala", } \\
\text { namely the } \\
\text { distribution of food } \\
\text { within the family, } \\
\text { and preparing } \\
\text { special meals for the } \\
\text { head of the family. }\end{array}$ & $\begin{array}{l}\text { - The tradition of } \\
\text { eating together } \\
\text { with family } \\
\text { members } \\
\text { - While eating, } \\
\text { food leftover is } \\
\text { forbidden }\end{array}$ \\
\hline
\end{tabular}

Source: Primary Data Analysis, 2020. 
Based on the data in Table 1, it shows that there is still local wisdom (both material and non-material aspects) in consumption activities starting from the process of preparing, cooking/ processing until the consuming of foodstuffs that are still practiced by the community in the study area. The traditions of Mappatala (eating together), forbidden in emptying Pabbaresengeng (rice container), and consuming local food sources such as pule utti, pule lame and lawa bale made of bananas, sweet potatoes, corn and various types of fish, enabling fishermen households to achieve food security. This is in line with the statement of [6], one effort that could improve the acceleration of food diversification in order to achieve food security is to restore the diversification of food consumption patterns rooted from local society since long time ago.

The research findings are in accordance with the opinion of [7] that strong food security is built at the household level that relies on the diversity of local resources. In line with the dynamics of stabilizing food security which is carried out by developing food sources, food institutions and food culture that are owned by the communities of each region. The advantages of this approach, among others, are the food that is produced locally is suitable with agricultural resources and the local climate, so that its availability can be pursued in a sustainable manner.

\subsection{Statistical Model of the Relationship between Household Food Security through Identification of Potential Local Wisdom Values in Coastal Agroecosystems}

In analysing the impact of the variables of education, knowledge, number of family members, food consumption patterns, household income, household expenditures, whether there is side job or not, and the value of local wisdom affecting the level of fishermen household food security, multiple linear regression analysis using the SPSS program is used.

Table 2 shows the results of the calculation of the correlation coefficient. The value of $\mathrm{R}=0.936$ means that the variables of education (x1), knowledge (x2), number of family members (x3), food consumption patterns (x4), household income (x5), household expenditure (x6), whether there is side job or not $(\mathrm{x} 7)$, and the value of local wisdom (x8) has a very strong impact $(93.6 \%)$ on the level of household food security in coastal communities. The coefficient of determination model ( $\mathrm{R}$ Square) is known to be 0.876 . This shows that the level of fishermen households' food security with the independent variable $(\mathrm{x} 1, \mathrm{x} 2, \ldots \mathrm{x} 8)$ has a high interrelation, which is equals to $87.6 \%$. The variable of food security level can be explained well by the independent variables (xi), while the remaining $12.4 \%$ is explained by other variables not included in this study.
Table 2. Correlation Coefficient Value of Observed Variables

\begin{tabular}{ccccc}
\hline Model & $\mathrm{R}$ & R Square & $\begin{array}{c}\text { Adjusted } \\
\text { R Square }\end{array}$ & $\begin{array}{c}\text { Std. Error } \\
\text { of the } \\
\text { Estimate }\end{array}$ \\
\hline 1 & 0.936 & 0.876 & 0.852 & 2.683
\end{tabular}

Source: Primary Data Analysis, 2020.

Table 3. Results of Partial Analysis of Household Food Security at the Coastal Agroecosystem, 2020

\begin{tabular}{|c|c|c|c|}
\hline Model & $\begin{array}{l}\text { Regression } \\
\text { Coefficient } \\
\text { (b ) }\end{array}$ & t-value & Sig. \\
\hline Constant & 35.137 & 5.756 & 0.000 \\
\hline Education $\left(\mathrm{x}_{1}\right)$ & 0.200 & 1.085 & 0.284 \\
\hline Knowledge $\left(\mathrm{x}_{2}\right)$ & 0836 & 0.808 & 0.424 \\
\hline $\begin{array}{l}\text { Number of Family } \\
\text { Members }\left(\mathrm{x}_{3}\right)\end{array}$ & -1.526 & -3.065 & 0.004 \\
\hline $\begin{array}{l}\text { Consumption Pattern } \\
\left(\mathrm{x}_{4}\right)\end{array}$ & 1.386 & 1.403 & 0.168 \\
\hline $\begin{array}{l}\text { Household Income } \\
\left(\mathrm{x}_{5}\right)\end{array}$ & -0.0005 & -0.495 & 0.623 \\
\hline $\begin{array}{l}\text { Household } \\
\text { Expenditure }\left(\mathrm{x}_{6}\right)\end{array}$ & -0.0003 & -2.737 & 0.009 \\
\hline $\begin{array}{l}\text { Whether there is side } \\
\text { job or not }\left(\mathrm{x}_{7}\right)\end{array}$ & 0.357 & 0.271 & 0.788 \\
\hline Local Wisdom $\left(\mathrm{x}_{8}\right)$ & 0.609 & 3.044 & 0.004 \\
\hline
\end{tabular}

The results of the joint analysis of the independent variables $(\mathrm{X})$ on the dependent variable $(\mathrm{Y})$ show that the effect of the independent variables $(X)$ on the dependent variable $(\mathrm{Y})$ "has a very significant effect" at the $5 \%$ and $1 \%$ levels. This shows that the regression model can be used to predict the level of household food security, because the significant value is smaller than the significant level $\alpha=0.05$.

Table 3 provides a statistical model of the regression equation for fishermen household food security in coastal agroecosystem as follows:

$\mathrm{Y}=35.137+0.200 \mathrm{X} 1+0.836 \mathrm{X} 2-1.526 \mathrm{X} 3+1.386$ $\mathrm{X} 4-0.0005 \mathrm{X} 5+0.0003 \mathrm{X} 6+0.357 \mathrm{X} 7+0.609 \mathrm{X} 8$

Partially, the t-test is used to test the significance of each independent variable. The t-test can be seen in the output coefficient in the column or the Sig. If the significant value $<\alpha=0.05$, then the variable has a significant effect.

The effect of the respondent's education (X1) on the level of household food security in coastal agroecosystem (Y) has a significant value of $0.284>$ 0.05. It can be concluded that the education level variable has no significant effect on the level of household food security. The education in question is formal education. In preparing, processing, and serving 
the food for household members, additional knowledge and skills are required, for instance taking courses in food processing skills, and so on. According to [8; 9; $10]$, the level of housewife education has no significant effect on household food security.

The effect of the respondent's knowledge (X2) on the level of household food security in coastal agroecosystem (Y) has a significant value of $0.424>$ 0.05 , this implies that the knowledge has no significant effect on the level of household food security. Knowledge of how to prepare, process and serve food ingredients of respondents is still very low. Skills on how to prepare, process and serve food are very rarely used because they think it is not something important. In addition, they shop only once a week, so that the food has reduced nutritional value. The serving of food ingredients should be served fresh. In contrast, a study by [11] found that the level of housewives knowledge has an effect on household food availability which will directly affect the status of household food security.

The of number of family dependents (X3) on the level of household food security in coastal areas (Y) has a significant value of $0.004<0.05$, which means that the number of family dependents has a significant effect on the level of household food security, with a negative coefficient direction. The regression coefficient value of the number of family members is -1.526 shows that by adding one family member, the level of household food security will decrease by 1.5 units. Thus, the greater the number of family dependents, the lower the level of food security. The number of family dependents is a characteristic related to household food consumption expenditure. The more the household members, the greater the cost, so that food consumption expenditure will also increase. The number of dependents of the respondents' family is on average 5 people, with the level of household food security in the food insecure category. This shows that family size is one of the factors that influence household food availability [12].

The significant value of the effect of the consumption pattern (X4) on the level of household food security in coastal agroecosystem (Y) is 0.168 > 0.05 . This interprets that the consumption pattern has no significant effect on the level of household food security. The consumption pattern is the composition of food including the frequency of meals per day. The daily dietary consumption pattern of respondents is very monotonous with the pattern of "staple food (rice) + vegetables + side dishes". This is monotonous food consumption pattern results in a low household food security score. Only a few respondents (10\%) consume fruit and milk, even then only 2-3 times a month. Similarly, [13] explains the types of food consumed by rural households are mostly rice and instant noodles.
The effect of income variables (X5) on the level of household food security in coastal areas (Y) has a significant value of $0.623>0.05$, which means that income have no significant effect on the level of household food security. The source of the respondent's income comes from farming and non-farming activities. According to the results of the study, the income of most of the respondent's households came from the main activity, namely fishing, while non-farm jobs were in the form of construction laborers, transportation services, etc. According to [14], income is an important factor in determining household expenditure, including household food consumption patterns. If income increases, food consumption patterns will be more diverse so that food consumption with high nutritional value can be achieved. The phenomenon that occurs in the research location is that an increase in income is not in line with the amount of household expenditure for food consumption. If income increases because the catch of sea products is abundant, it is allocated for non-food expenditures, for example buying secondary needs, such as electronic goods, spending for social needs, etc.

The expenditure for food (X6) has significant effect on the level of household food security. Household food expenditure is an indicator of household food security. The greater the share of a household's food expenditure, the lower its level of food security. Therefore, the composition of household expenditure can be used as an indicator to measure household food security. The lower the share of expenditure on food, the better the level of community welfare [15]. Moreover, [16] reported that the neighbourhood and consumption habits affect household food security, for instance households in urban areas generally have a lower proportion of rice expenditure so that their share of food expenditure will be low and have a high level of food security, contrarily with households living in the rural areas because generally their proportion of rice expenditure is quite high, resulting in a high share of food expenditure and low food security.

The effect of side jobs (X7) on the level of household food security in coastal agroecosystem (Y) has a significant value of $0.888>\alpha=0.05$ (not significant). There is a lack of availability of side jobs in the study area makes the household income low. The respondents are only rely on the catch of marine products. Low income can affect the level and pattern of household food consumption which then affecting household food security.

The local wisdom (X8) has a significant effect on the level of household food security in coastal agroecosystem (Y), with a significant value of $0.004<$ 0.05 (positive coefficient direction). This means that the more respondents apply the values of local wisdom in achieving food needs, the more food resilient they 
are. The form of local wisdom referred to in this research is that respondents still pay attention to and carry out requests or restrictions that apply locally from generation to generation in the area, both in preparing local food ingredients, processing/ cooking local food ingredients, until how to serve local food ingredients. This is in line with [17] that states the strategy to achieve national food security is to strengthen local wisdom as the basis for national food storage. In addition, local food is a source of staple food and snacks for rural communities and it became a mainstay to ensure the fulfilment of food needs and overcome the threat of hunger or food crisis [18].

\section{CONCLUSION}

The fishing community still implements local wisdom in preparing, processing and consuming food such as preparing food reserves in the household, the tradition of "mappatala" (eating together), pamali/ not emptying the rice container (pabbarassengeng) in the house, and consuming local food sources such as pule utti, pule lame and lawa bale made from banana, sweet potatoes, maize and various types of fish allow fishermen households to achieve food security. This resulting to coastal agroecosystem communities never experience hunger, although there is scarcity of rice, because the community has independently prepared food reserves. The results of the partial analysis of the independent variable $(\mathrm{X})$ on the dependent variable $(\mathrm{Y})$ found that the variables of the number of family members, household expenditure, and the value of local wisdom had a "significant effect" on the level of fishermen household food security.

\section{ACKNOWLEDGMENTS}

Thanks to the Ministry of Research and Technology and Higher Education (RISTEK-DIKTI) of the Republic of Indonesia for providing financial assistance, and Universitas Muslim Indonesia so that this research can be carried out.

\section{REFERENCES}

[1] A.J. Athur, Coastal Community: International Perspectives, in The $26^{\text {th }}$ Annual Meeting of The Canadian Commissionfor Unesco, St Jhon's Newfoundland, 6th June1984.

[2] B.H. Purnomo, A. Machfud, Hermawan, E.S. Wiyono, "Model Prediksi Keberlanjutan Sumberdaya Ekonomi pada Agroindustri Teri Nasi”, J.Tek.Ind. Pert, 21(3) 2011163 - 175.

[3] Arikunto, Prosedur Penelitian Ilmiah Suatu Pendekatan Praktis, Jakarta: Rineka Cipta, 1993.

[4] L.C. Smith, A. Subandoro, Measuring Food Security Using Household Expenditure Surveys,
Washington D.C.: International Food Policy Reseacrh Institute, 2007.

[5] Aprodev, No Security Without Food Security No Food Security Without Gender Equality, Report Of Good Conference, 2002.

[6] Tupan, Wujudkan Ketahanan Pangan dengan Kearifan Lokal, 2011 humanitarianforumindonesia.org/LinkClick.aspx?f ileticket $=$ GNVCYk54hCw\%3D\&tabid $=648 \& \mathrm{mid}=$ 1526.

[7] Suhardjo, Pengertian dan Kerangka Pikir Ketahanan Pangan Rumah Tangga in Lokakarya Ketahanan Pangan Rumah Tangga, 1996.

[8] E. Herdiana, Analisis Jalur Faktor-Faktor yang Mempengaruhi Ketahanan Pangan Rumah Tangga di Kabupaten Lebak, Propinsi Banten. Skripsi. Departemen Gizi Masyarakat. Fakultas Ekologi Manusia. Institut Pertanian Bogor. Bogor, 2009.

[9] A. N. Hidayati, Analisis Tingkat Ketahanan Pangan dan Kesejahteraan Rumah Tangga Petani di Kecamatan Metro Utara Kota Metro, Skripsi, Jurusan Agribisnis. Fakultas Pertanian. Universitas Lampung, Bandar Lampung, 2011

[10] R. Desfaryani, Analisis Ketahanan Pangan Rumah Tangga Petani Padi di Kabupaten Lampung Tengah, Skripsi, Jurusan Agribisnis, Fakultas Pertanian, Universitas Lampung, Bandar Lampung, 2012

[11] U. Iram, M.S. Butt, "Determinants of Household Food Security: An Empirical Analysis for Pakistan", International Journal of Social Economics, 31(8) (2004) 753-766. DOI: $10.1108 / 03068290410546011$

[12] K. Sukiyono, I. Cahyadinata, N. F. N. Sriyoto, "Status Wanita dan Ketahanan Pangan Rumah Tangga Nelayan dan Petani Padi di Kabupaten Muko-Muko Provisi Bengkulu", Jurnal Agro Ekonomi, 26 (2) (2008) 191-207, DOI: http://dx.doi.org/10.21082/jae.v26n2.2008.191-207

[13] I. R. Aneftasari, B. Arifin, Y. Indriani, "Determinan Pola Pangan Harapan pada Rumahtangga Buruh Pengasin Ikan di Pulau Pasaran", JIIA, 4(3) (2016) 301-308.

[14] E. Rahmawaty, “Aspek Distribusi pada Ketahanan Pangan Masyarakat di Kabupaten Tapin", Jurnal Agribisnis Pedesaan, 2(3) (2012) 241-251.

[15] M. Ariani, E. Ariningsih, I.K. Kariyasa, M. Maulana, Kinerja dan Prospek Pemberdayaan Rumahtangga Rawan Pangan dalam Era Desentralisasi. Kerjasama Penelitian Biro Perencanaan, Departemen Pertanian, dan UNESCAP-CAPSA, Bogor. Departemen Pertanian, 2004. Kinerja Sektor Pertanian 20002003, Jakarta, 2007 
[16] P. Yunastiti, S. Hartono, Masyuri, J.M. Handoyono, "Pola Pengeluaran Pangan Rumah Tangga Menurut Tingkat Ketahanan Pangan di Provinsi Jawa Tengah". Jurnal Ekonomi Pembangunan: Kajian Masalah Ekonomi dan Pembangunan. 11 (2) (2015) 236-253. DOI: https://doi.org/10.23917/jep.v11i2.327

[17] S.S. Cahyanto, S.P. Bonifasius, A. Muktaman, Penguatan Kearifan Lokal in Prosiding the 4th
International Conference on Indonesian Studies, 2012

[18] A. Fadhilah, "Kearifan Lokal dalam Membentuk Daya Pangan Lokal Komunitas Molamahu Pulubala Gorontalo", Buletin Al-Turās̀ 19(1) (2013) 23-38, DOI: https://doi.org/10.15408/bat.v19i1.3696 